\title{
Acer-Fraxinus dominated woods of the Italian peninsula: a floristic and phytogeographical analysis
}

\author{
Claudia Angiolini ${ }^{1 *}$, Bruno Foggi $^{2}$, Daniele Viciani² \\ ${ }^{1}$ Department of Environmental Science, University of Siena, Via P.A. Mattioli 4, 53100, Siena, Italy \\ ${ }^{2}$ Department of Evolutionary Biology, University of Florence, Via La Pira 4, 50121, Florence, Italy
}

\section{Abstract}

Forest communities dominated by noble broad-leaved trees (maple, lime and ash) in Europe are of elevated scientific and conservation interest for the European Union. In this paper, we first present a synthesis of the maple and ash forests in peninsular Italy. By classifying these forests, we distinguish seven main groups for the territory, which only broadly match the syntaxa proposed in the literature. The variability of the Apennine data is then analysed floristically and phytogeographically (using chorological components) in a central-southern European context, using numerical classification, INSPAN, and direct ordination of several synoptic tables. These analyses allow us to identify six different groups of European Acer-Fraxinus communities. Canonical Variates Analysis (CVA) of the geographical components confirms the existence of distinct phytogeographical groups. In particular, we highlight the clear distinction between central European (including the Alps) and southern European coenoses. Among the latter there was a clear floristic and chorological distinction between Balkan and Apennine groups. These results reflect the biogeographical subdivisions of Europe, but do not support the syntaxonomical schemes proposed by other authors, which are based only on floristic-ecological information or (recently) use a smaller data set of Italian relevés. This study also shows that syntaxonomical schemes above the association level should pay more attention to phytogeographical aspects rather than focus on floristic-ecological information alone, in order to propose models that are of value on a geographical scale.

Keywords: Apennine, biogeography, Italy, mixed broad-leaved woods, numerical methods, syntaxonomy, Tilio-Acerion

\section{Introduction}

Hilly and mountain mixed mesophilous woods dominated by Acer spp. and Fraxinus excelsior are considered of great scientific and conservation interest in Europe and are considered a priority habitat by the European Union (cod. Natura 2000: 9180, Annex I of Directive 92/ 43). According to the latest version of the "Interpretation Manual of European Union Habitats" [1,2] this habitat encompasses "Mixed forests of secondary species (Acer pseudoplatanus, Fraxinus excelsior, Ulmus glabra, Tilia platyphyllos, T. cordata) of coarse scree, abrupt rocky slopes or coarse colluvial deposits of slopes, particularly on calcareous, but also on siliceous, substrates" and is present in practically all European countries. Nonetheless, Acer spp. and Fraxinus excelsior woods are rare and cover small surfaces throughout Europe, as forest management in the past often directly or indirectly favoured other tree species (particularly

* Corresponding author. Email: angiolini@unisi.it

This is an Open Access digital version of the article distributed under the terms of the Creative Commons Attribution 3.0 License (creativecommons.org/licenses/by/3.0/), which permits redistribution, commercial and non-commercial, provided that the article is properly cited.
Fagus sylvatica and conifers) rather than the so-called "noble broadleaves" (Acer spp., Fraxinus excelsior, Ulmus glabra, Tilia spp.) that form the characteristic dominant layer of this habitat [3]. Nowadays, in the mountain chains of central-southern Europe (i.e. the Apennines and Dinaric Alps) the most typical coenoses are located in relatively inaccessible sites and should be considered as relicts. These mixed maple and ash woods are capable of developing in quite diverse habitats: on steep slopes or ravines, on rocky or stony screes, at the bottom of shady steep-sided valleys, on deep colluvial soils at the foot of slopes, in generally mesophilous conditions but also in relatively thermophilous places, on humus-rich and more or less base-rich soils [4].

Klika [5] was the first author to highlight the phytosociological autonomy of these forests, defining the phytosociological alliance Tilio platyphylli-Acerion pseudoplatani Klika 1955 s.l. for these central European hilly and submontane mixed coenoses, characterized by specific flora and a European (from western to central and south-eastern) distribution.

Numerous local studies concerning the mountains of central Europe and the Balkan regions are available [5-18], together with more or less large-scale reviews [3,19-23]. Regarding the Italian Alps, a few studies have focused on the eastern part [24,25]; until a few years ago, information concerning Tilio-Acerion coenoses on the rest of the Italian peninsula was often sporadic, based on structural aspects and on limited relevés [26-30]. However, several studies concerning maple 
and ash woods have been published more recently, with larger datasets referring to different peninsular areas [31-38]. The results of these studies suggest a strong phytogeographic differentiation of Acer-Fraxinus woods from Alpine regions to the Apennines, especially in the southernmost areas of the latter range. In particular Brullo et al. [32] described a new alliance for mixed forests in southern Apennine areas with a Mediterranean bioclimate - Tilio pseudorubrae-Ostryion carpinifoliae Brullo, Scelsi, Siracusa and Spampinato 1999 - which was subsequently divided in two sub-alliances by Ubaldi $[39,40]$, and assigned to the Quercetalia pubescentis order by Biondi et al. [41]. The new alliance Lauro nobilis-Tilion platyphylli Biondi, Casavecchia and Biscotti 2008, recently described by Biondi et al. [41] for the Tilia and Acer woods in the southern Apennines, could also be considered as a geographic vicariant of Tilio-Acerion. In fact, according to Košir et al. [42] and Biondi et al. [41] the southern limit of the Tilio-Acerion suballiance in the Apennine, represented by the association Aro lucani-Aceretum lobelii, is the Matese Massif (Campania, Molise). In this paper, we address the following questions regarding maple-ash coenoses ascribed to Tilio-Acerion, using a large dataset and various numerical methods: (i) Which types of Italian peninsular Acer-Fraxinus community can be distinguished from a phytosociological viewpoint, based on a large (114 relevés) data set? What are the possible reasons for these patterns? (ii) What are the floristic differences between the Italian peninsular Tilio-Acerion (s.l.) communities and the similar Alpine, central European and Balkan coenoses? Can these differences be used to identify phytogeographical gradients? (iii) Does the differentiation of the Acer-Fraxinus woodlands in the Apennines reflect their attribution to a single suballiance (Ostryo-Tilienion platyphylli) together with some Balkan coenoses, as reported by Košir et al. [42]?

\section{Material and methods}

This study concerned only Tilio-Acerion woods dominated by Acer spp. and Fraxinus excelsior sometimes with Tilia platyphyllos. Tilia cordata dominated coenoses are excluded, as their presence on the Italian peninsula is limited and they are considered by several authors to be more thermophilous and well-differentiated [3,43-45]. The study takes into consideration 114 phytosociological relevés performed according to the Braun-Blanquet method [46] in Acer spp., Tilia platyphyllos and Fraxinus excelsior dominated woods on the Italian peninsula. The relevés, some of which were unpublished, were performed by different authors [31,33-38] along a geographical gradient of approximately $600 \mathrm{~km}$ in length (Tab. S1). They were classified numerically using TWINSPAN as divisive polythetic method [47] in order to characterize homogeneous floristic groups defined in a large-scale classification [48] and to avoid the problem of existing syntaxa based on a single/few relevés, without suitable synoptic tables. Five pseudo-species cut levels were selected, corresponding to $0,2,3,5$ and 7 .

For floristic comparison of the data for the Italian peninsula (7 synoptic tables corresponding to the numerical classification groups), 17 vegetation tables of Acer-Fraxinus dominated forests in the Alps, central and south-eastern Europe were selected $[6,10,11,15-18,24,25,49-53]$. Furthermore, 6 synoptic tables from unavailable literature were taken directly from [3]. With these data a matrix was prepared in the form of constancy tables, with constancy classes 1 to $5(1=1-20 \%$; 2
$=21-40 \%, 3=41-60 \% ; 4=61-80 \%$ and $5=81-100 \%)$, then examined using the same classification methods (matrix $30 \times 247$, using only species with a frequency $\geq 3$; the 4 cut levels were $0,2,3$ and 4).

To detect the representative species in each group obtained by the latter classification, we used INdicator SPecies ANalysis (INSPAN) [54]. This method combines information on the species abundance and the faithfulness of occurrence of a species in a particular group. First, we calculated an indicator value for each species (the product of its relative abundance and relative frequency), ranging from 0 (no indication) to 100 (perfect indication). Secondly, we tested the statistical significance of the highest indicator value $\left(I V_{\max }\right)$ for each species using a Monte Carlo method that randomly assigns each sample to groups 999 times. The null hypothesis is that $I V_{\max }$ is no larger than would be expected by chance (i.e. that the species has no indicator value). To test for significance, we set $\alpha$ at 0.05 . We used PC-ORD software [55] to conduct all procedures.

A table of southern European Acer-Fraxinus dominated woods was subsequently constructed with the communities and species ordered according to the classification results, and showing significant indicator species for each cluster.

To characterize the role of various phytogeographical groups of species (chorotypes) in the communities examined, the species were allocated to 14 groups in all synoptic tables: Alpine, Alpine-Apennine, Apennine, central-southern Apennine, Apennine-Balkan (including Dinaric Alps), Balkan (including Dinaric Alps), Mediterranean, European-Mediterranean, Eurosiberian-Tethyan (including European-Tethyan), east European (E and S European), Eurosiberian (including European), Boreal, Holarctic and Cosmopolitan. The species were allocated to these groups based on their chorological types, in accordance with the phytogeographical synthesis of Takhtadjian et al. [56] and Takhtadjian and Cronquist [57], with some variation for chorotypes above the province level as reported by Arrigoni [58] and Foggi [59].

To identify patterns in phytogeographical variation among the groups of relevés identified by numerical classification, discriminant analysis of the last TWINSPAN classification groups treated as nominal species was performed using Canonical Variates Analysis (CVA), with the percentage of chorotypes in each phytocoenosis as the environmental variables [60]. As there were fourteen (14) potentially relevant phytogeographical attributes, we used a forward selection procedure [61] to find the minimal set of statistically significant attributes that "explain", in a statistical sense, the relevé groups about as well as the full fourteen chorotypes. To assess statistical significance in the forward selection procedure, we used an unrestricted Monte Carlo test. The significance level of the tests in the CVA was adjusted according to the Bonferroni method of correcting for multiple tests, in order to rectify type I errors due to the repeated statistical tests [62]. The lengths of environmental variable arrows were adjusted to better express their discriminating power, using within-group standard deviation a as reference scale [63].

The CANOCO package (version 4.5) [60] was used for ordination analyses and multiple linear regression. Significance was tested at each step of the stepwise multiple and partial regression analyses and for the axes of the ordination analyses, using a Monte Carlo permutation test with 999 random permutations.

Species nomenclature is in accordance [64-67]. 
Results

\section{Classification of the Italian peninsular relevés}

The TWINSPAN classification of the Italian peninsula relevés cutting at the third cut level (see dendrogram in Fig. 1) shows 7 groups, which can be interpreted as 7 vegetation types (Tab. S1). These types are well characterized by the presence or absence of the diagnostic species groups indicated by the numerical analysis. The floristic-ecological differences between these groups may be summarized as follows: GROUP 1: Ravine woodlands of the Matese mountains (Molise, southern Apennines) on deep colluvial soils derived from carbonate rocks (Aro lucani-Aceretum lobelii Paura and Cutini 2006). GROUP 2: Acer spp., Abies alba, Fraxinus excelsior woods on colluvial deposits of slopes in Abruzzo and Basilicata (central and southern Apennines, Aceretum obtusati-pseudoplatani aceretosum lobelii Pirone et al. 2006 and unpublished data). TWINSPAN indicator species are Corylus avellana and Rubus hirtus. GROUP 3: Low mountain mixed woods dominated by Acer obtusatum, A. pseudoplatanus and Fraxinus excelsior on mainly siliceous rocky and colluvial in Marche, Tuscany and Latium (central Apennines and anti-Apennines; OrnithogaloAceretum Taffetani 2000 and unpublished relevés). TWINSPAN indicator species are Lonicera caprifolium, Fraxinus ornus and Carpinus betulus. GROUP 4: Hilly and low mountain Acer spp., Ulmus glabra and Tilia platyphyllos mixed woods on substrates with the presence of large calcareous rocks or at the base of steep slopes where layers of detritus gather (Marche, central Apennines, Aceretum obtusati-pseudoplatani Biondi et al. 2002, Aceretum obtusati-pseudoplatani asperuletosum taurinae Allegrezza 2003; Aceri-Ulmetum Pedrotti 1982 and unpublished data). TWINSPAN indicator species are Saxifraga rotundifolia, Ostrya carpinifolia and Asperula taurina. GROUP 5: Low mountain mixed woods dominated by Acer spp. and Fraxinus excelsior, mainly on basic colluvial and rocky soils in Marche and marginally Tuscany (central Apennines, Ornithogalo-Aceretum [36]; Aceretum obtusatipseudoplatani aconitetosum neapolitani Allegrezza 2003 and unpublished data). GROUP 6: Mixed sub-thermophilous woods in calcareous ravines with Acer obtusatum, A. campestre and Ostrya carpinifolia in southern Tuscany (anti-Apennines, Glechomo hirsutae-Aceretum obtusati Angiolini et al. 2005). TWINSPAN indicator species are Cornus mas and Glechoma hirsuta. GROUP 7: Low mountain mixed woods dominated by Acer spp., Fraxinus excelsior and Ostrya carpinifolia mainly on clay soils derived from basic Flysch substrates in Tuscany (central Apennines, Ornithogalo-Aceretum geranietosum nodosi Angiolini et al. 2005). TWINSPAN indicator species are Ostrya carpinifolia, Geranium nodosum, Anemone trifolia and Cardamine heptaphylla.

\section{Classification of the Alpine and southern European forests}

The classification according to TWINSPAN (Fig. 2) separates two clusters at the first level. The first cluster comprises Alpine belt coenoses, including intra-Alpine, central European and peripheral eastern areas (groups A, B and C; Fig. 3). The second cluster comprises coenoses of the southern peri-Alpine belt and that of the Apennines and the Dinaric Alps (groups D, E and F; Fig. 3); indicator species are Ostrya carpinifolia, Cornus mas, Fraxinus ornus and Melica uniflora.

Group A is distributed in hilly and mountain environments along the entire Alpine belt. The dataset comprises four

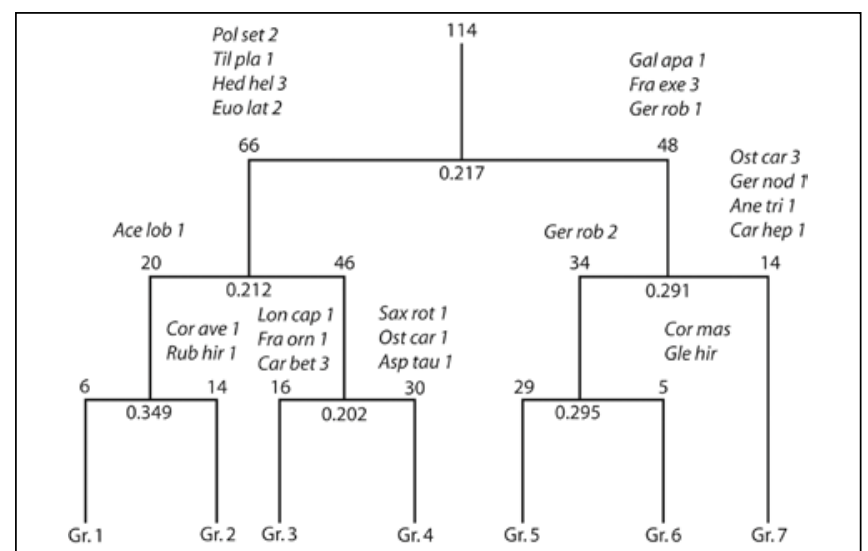

Fig. 1 TWINSPAN dendrogram of 114 relevés in Acer-Fraxinus forests along the Italian peninsula. Indicator species are shown using the first three letters of the genus and species names from Tab. S1.

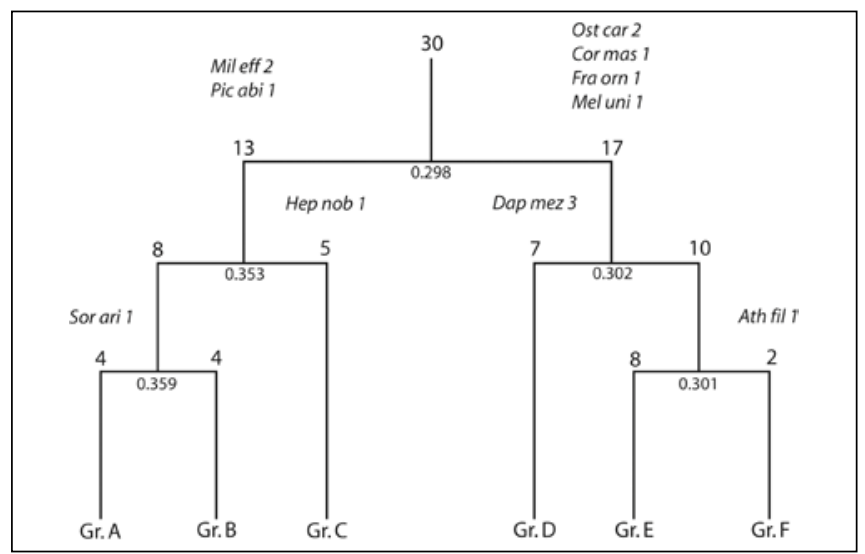

Fig. 2 TWINSPAN dendrogram of 30 synoptic vegetation tables of Acer-Fraxinus dominated forests from the Alps, Apennines, central and south-eastern Europe. Indicator species names at each division are abbreviated to first three letters of the genus and species names from Tab. S2.

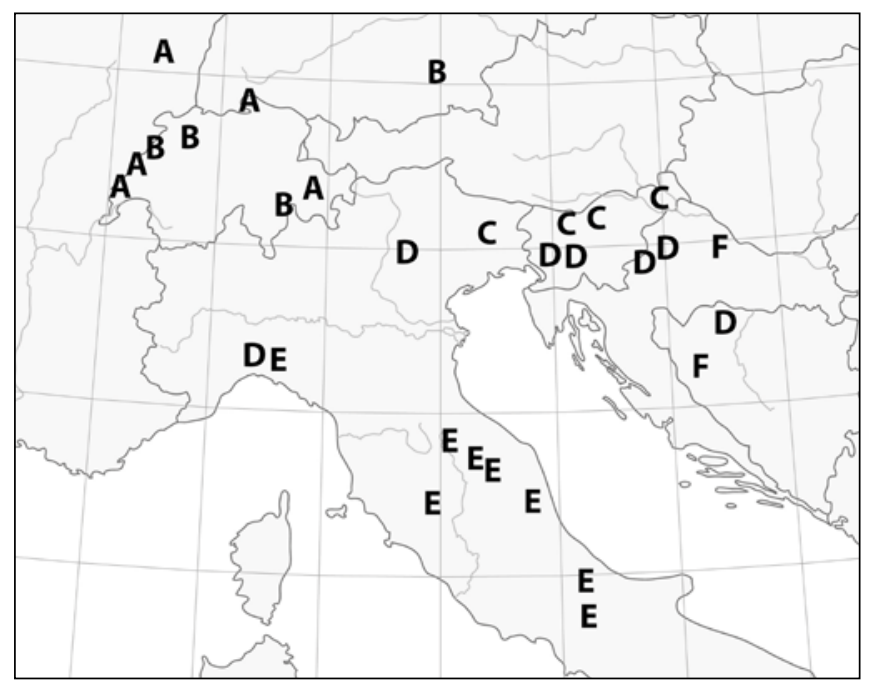

Fig. 3 Distribution map of forest relevés in central and southern Europe. The letters shown correspond to the six European groups shown in Fig. 2 (TWINSPAN classification). 
phytosociological tables for the Jura, Vosges, and Grigioni mountains. They include coenoses dominated by Acer pseudoplatanus with Fraxinus excelsior, Tilia platyphyllos, Ulmus glabra, numerous microthermic species and plants typical of fir and spruce woods. The indicator species according to TWINSPAN is Sorbus aria and, according to INSPAN, the group appears well-differentiated, having numerous representative species (Tab. S2). The species that were not unique to this cluster but markedly less frequent in the other communities were Adenostyles alpina, Hordelymus europaeus, Cardamine heptaphylla, polygonatum verticillatum, Rosa pendulina, Rubus saxatilis, etc. (for symmetrical indicators, see [54]). Other less frequent species that had their maximum indicator values in this group (asymmetrical indicators) were Gymnocarpium robertianum, Salix appendiculata, Knautia dipsacifolia, Viola biflora.

Group B - southern-central submontane Alpine group. The four tables analyzed are related to the Jura Mountains, Switzerland, and southern Germany. They include coenoses dominated by Acer pseudoplatanus, A. platanoides, Fraxinus excelsior and Abies alba, similarly to those of group A, but the species are less characterizing here. INSPAN indicates the presence of significant indicator species (Abies alba, Impatiens noli-tangere, Stachys sylvatica, Scrophularia nodosa, etc.) that are generally also quite frequent in other clusters (in particular A and C).

Group C - coenoses of the south-eastern Alpine belt, distributed from north-eastern Italy (Veneto and Friuli) to Slovenia (Hacquetio-Fraxinetum s.l.). The group includes coenoses with many hilly and submontane species together with numerous mesophilous gorge species. The canopy is dominated by Fraxinus excelsior and, to a lesser extent, by Carpinus betulus, Ulmus glabra, and prunus avium. According to TWINSPAN the indicator species is Hepatica nobilis. INSPAN indicated that the group is floristically well-defined, with a high number of significant symmetrical species (e.g. Listera ovata, Cirsium oleraceum, Anemone ranunculoides, Chrysosplenium alternifolium, Dryopteris carthusiana, Deschampsia caespitosa, etc.), some of which are distributed in the Balkans and in central Europe (e.g. Hacquetia epipactis, Cardamine trifolia, Lamium orvala), or indicate zonal contacts (e.g. picea abies).

Group D - mixed group of coenoses prevalently from the eastern peri-Alpine zone. The 7 tables analyzed refer to northern (mainly north-eastern) Italy, Croatia, and Slovenia. The group includes coenoses of calcareous substrates dominated by Acer spp. and Ulmus glabra, together with Tilia platyphyllos, Taxus baccata, Ostrya carpinifolia and Fraxinus ornus, all markedly south-eastern European; it is characterized by microthermic species (TWINSPAN indicator species: Daphne mezereum) but differentiated from the Alpine coenoses thanks to numerous species of rocky/unstable substrates (Calamagrostis varia, Sesleria autumnalis, Lonicera xylosteum, Valeriana tripteris, Sorbus aria, etc.) and to some thermophilous species (Ruscus aculeatus, Tanacetum corymbosum, Vinca minor). INSPAN reveals that the group is well-defined; the indicator species include some from the surrounding zonal woods (i.e. Ostrya carpinifolia, Fraxinus ornus, Rosa arvensis) and others with a prevalently eastern distribution (Corydalis ochroleuca, Euonymus verrucosus, Sesleria autumnalis, etc.).

Group E - submontane coenoses of the Apennines (from central-northern to central-southern), typical of both calcareous and siliceous substrates, dominated by Acer spp. The 7 tables analyzed all refer to peninsular Italy (Liguria, Tuscany,
Marche, Abruzzo, Molise). According to INSPAN the indicator species are only 29 (see Tab. S2); most of these are not exclusive to the group, but reach their maximum frequency and coverage in it. Among these, the most significant woody species are: Acer obtusatum, with a southern European distribution, which characterizes and dominates maple woods on the Italian peninsula; Quercus cerris, an European-Mediterranean plant that penetrates into the Apennine Tilio-Acerion populations with limited coverage, indicating its contact with the neighbouring zonal coenoses; Ilex aquifolium, another European-Mediterranean sub-thermophilous plant present almost exclusively in Apennine coenoses, indicating the relict character of these woods. Among the herbaceous species we underline the presence of endemic Apennine species such as pulmonaria apennina, Helleborus bocconei, Lilium bulbiferum ssp. croceum, Digitalis micrantha, and European-Mediterranean species like Melica uniflora, Daphne laureola, Viola alba ssp. dehnhardtii.

Group F with two tables relating to Bosnia and Croatia. This group includes mixed coenoses of the central parts of the Dinaric Alps, dominated by Acer spp., with Tilia cordata, and Carpinus betulus. The indicator species according to TWINSPAN is Athyrium filix-femina, while INSPAN indicated only 7 significant species for the group, among which we highlight Tilia cordata, as well as the mesothermophilous species Crataegus monogyna and Ajuga reptans. In terms of floristic composition, this group represents the transition from Apennine to Balkan peri-Alpine coenoses.

\section{Discriminant analysis}

The CVA results show clear phytogeographical variations among the communities (Fig. 4). Six of the 14 chorotypes defined are significantly related to the differences between relevé groups (European-Mediterranean, east-European, Eurosiberian, Boreal and Holarctic at $p=0.001$; Apennine at $p=$ $0.003)$. Twenty seven percent of the within-to-between group variation is captured in CVA axes 1 and 2 (axis 1: 13.9\%; axis 2: $13.1 \%)$. Four CVA axes are highly significant $(p<0.001)$, but the general pattern of phytogeographical variation among

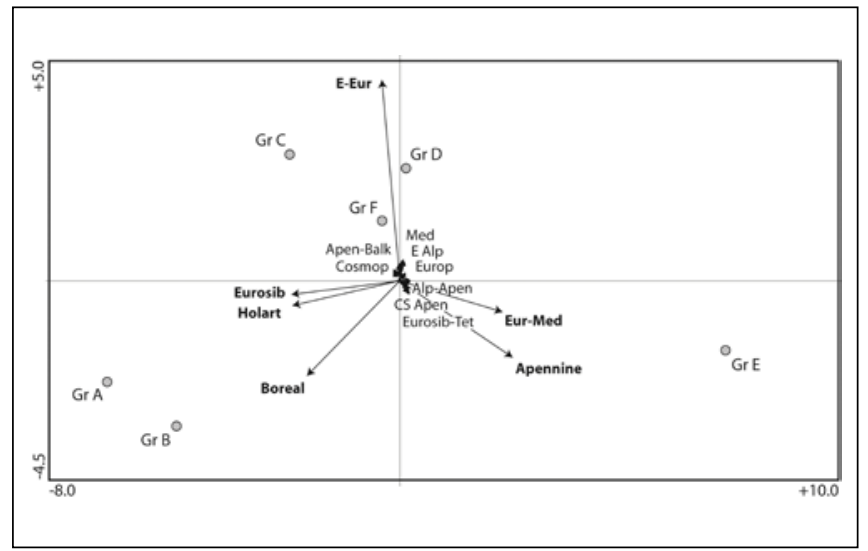

Fig. 4 Ordination of the relevé groups along the first two CVA axes in relation to the 14 phytogeographical groups of species: E-Alp (eastern Alpine), Alp-App (Alpine-Apennine), Apennine, CS Apen (central-southern Apennine), Apen-Balk (Apennine-Balkan), Balkan (including Dinaric Alps), Med (Mediterranean), Eur-Med (European-Mediterranean), Eurosib-Tet (Eurosiberian-Tethyan including European-Tethyan), E-Eur (eastern and southern European), Eurosib (Eurosiberian including European), Boreal, Holarct (Holarctic) and Cosmop (Cosmopolitan). Labelling of relevé groups as in Fig. 2. 
the communities is shown most clearly by the combination of the first and second axes (Fig. 4). CVA axis 1 is most closely positively correlated with European-Mediterranean $(r=0.79)$ and Apennine $(r=0.78)$ species, but negatively connected with Eurosiberian $(r=-0.83)$, Holarctic $(r=-0.77)$ and Boreal $(r=$ $-0.64)$ species. This axis separates the communities of Italian peninsular Acer-Fraxinus woods (Group E) from all the other groups; the extreme positions along the arrows pointing in the opposite direction from the European-Mediterranean and Apennine species are occupied by the communities poorest in these species (Groups A and B). The number of east-European species is most closely positively correlated with the second axis $(r=0.86)$ and strongly influences the ordination of communities along this axis from the poorest (Groups A and B) to the richest (Groups $\mathrm{C}$ and $\mathrm{D}$ ) in these species. Along this axis, Italian peninsular coenoses (Group E) occupy an intermediate position even though they are located on the negative side, thus highlighting the scarce presence of east-European components.

\section{Discussion}

For the Italian peninsula, the seven groups proposed by numerical classification based on a large dataset only represented some of the original phytosociological syntaxa (Groups 1, 2, 6 and 7), while the other associations were split or clustered (Groups 3, 4 and 5; Fig. 1). This was predictable since, as recorded by Knollová et al. [48], analyses based on large datasets identify groups of relevés that occupy larger areas than those identified by local datasets. In particular, it is clear that the more highly characterized sociological groups (e.g. by Acer lobelii, a central-southern Apennine species, or Geranium nodosum, a subacidophilous species) belong to peripheral mountain groups that are geographically and biogeographically isolated. On the contrary, relevé groups 3, 4, and 5 from the central Apennines are less well-defined and show floristic exchanges and overlapping due to geographical-ecological continuity. This strong connection determines the presence of a high number of species (some with high cover values) in common with the woodlands in spatial contact with maple-ash woods, such as mixed mesohygrophilous broadleaved woods (e.g. Carpinus betulus, Corylus avellana coenoses), or thermophilous woods (e.g. Ostrya carpinifolia and Fraxinus ornus stands). This floristic contiguity with deciduous broadleaved woodlands can be explained through vegetation history. According to Pott [68], in the Atlantic period (6000-3200 BC) broadleaved woods were composed of Ulmus sp., Quercus sp., Tilia sp., Fraxinus excelsior, Acer sp., and Alnus glutinosa. During the second half of the Atlantic, and above all in the subsequent Sub-Boreal period [68-71], the expansion of beeches began, starting from the southern refugia and conquering all areas, especially those with mixed woodlands of Abies, Tilia, Fraxinus and Acer (see [72]). This phenomenon could have determined a certain homogenization of the pre-existing populations, levelling out their floristic differences. This is likely to have happened above all in areas such as the central Apennines, which maintained strong functional connections with surrounding areas for historical and geographical reasons and thus developed less characterized endemic components than elsewhere. Within this general trend, the human effect favoured the local expansion of beeches in relation to the noble broadleaved trees, as also reported by Ubaldi [73]. In this case the effects of ecological closeness [74] need to be well quantified and analyzed in order to reveal their possible influence.
In the European context, this study confirms the results of the paper by Košir et al. [42] and demonstrates that Alpine, south-east European, and Apennine groups are autonomous. This strong differentiation is attributable to the endemic species groups being better conserved in these azonal coenoses, with a "buffered" flora with respect to other more closely interconnected woodlands, to the limited effect of the human disturbance, which can be seen in the station characteristics and finally to the species from zonal woods in contact with maple-ash woods, which differ in function of different biogeographical regions.

Nevertheless, the greatest differences recorded are between the Alpine and surrounding European coenoses: either between northern Alpine and central European (Groups A and B) species, or between eastern Alpine (Group C) species and those of the southern chains (Groups D, E, F; Fig. 2). This strong differentiation of the Alpine coenoses s.l. is also suggested by CVA (Fig. 4), which proves that there is a substantial difference between Alpine maple-ash and other woods, especially Apennine ones. In fact, species with very broad ranges, the history of which may be more closely connected with boreal woods (e.g. Rubus idaeus, Impatiens noli-tangere, Dryopteris carthusiana, Angelica sylvestris, etc.), are present almost exclusively within Alpine maple-ash woods. To these we must add a group of nemoral European-Mediterranean species which are remnants of the rich forest vegetation of the warm and humid periods of the Middle and Late Tertiary. These species are sensitive to climatic conditions and strictly European-Mediterranean, and as such absent or sporadic in Alpine maple-ash woods (e.g. Euonymus latifolius, Fraxinus ornus, Ostrya carpinifolia, Viola alba, Daphne laureola, Taxus baccata, Ilex aquifolium, Hypericum montanum, etc., see Tab. S2). The northern limits of these taxa exhibit a continuous gradation, but only a few extend into the temperate central European region [75].

Considering the Apennine coenoses, classification (Fig. 2) reveals a relative (although still limited) affinity between them and the groups less influenced by the Alpine belt in the central and southern parts of the Dinaric Alps. This also emerges from the studies of several Balkan authors [76,77] and in particular from [78], who propose the attribution of Apennine and Dinaric Alpine maple-ash woods to the alliance Fraxino-Acerion Fukarek 1969, including two new suballiances distinguished on a floristic-ecological basis. In a later paper, Košir et al. [42] state that classification into the independent alliance proposed by Fukarek [43] is not a suitable solution, as they did not succeed in confirming it by numerical analyses. Their numerical analyses show that xerothermophilous and mesophilous broad-leaved ravine forests in different phytogeographic regions are more similar than xerothermophilous and mesophilous forests in a single region. Thus, Košir et al. [42] base their classification on ecologically as well as geographically differential groups. Stressing the importance of the dominant trees, they propose classifying the Apennine coenoses, together with some Balkan ones (of the southern Balkan to Illyrian area), into a new suballiance of Tilio-Acerion, named Ostryo carpinifoliae-Tilienion platyphylli. The presence of a single suballiance encompassing both the Apennine and Balkan coenoses was justified by Košir et al. [42] on a historical basis. In fact, the refugia of the Apennine-Illyrian vegetation are localized in the central and southern Apennines and in the southern part of the Balkan peninsula [71,72,79-81]. This common paleogeographical history is responsible for the high number of species with Apennine-Balkan distribution (i.e. 
in Tab. S2 Acer obtusatum s.l. and Acer lobelii). However, it should be stressed that maple-ash woods are not the vegetation type within which phytogeographic relationships between the Apennines and Balkans are most evident. This is also indicated by our ordination (Fig. 4), which shows the clear autonomy of the Italian peninsula coenoses, caused by the consistent number of European-Mediterranean species and the Apennine endemics, together with the scarcity of east-European species. The results of our chorological analyses differ consistently from those of Košir et al. [42], as these authors consider the Apennine and Balkan coenoses to be very similar from a chorological viewpoint. This may be due either to a different chorological treatment ([42] followed $[82,83])$ or to our larger dataset of Italian relevés (Košir et al. [42] had a larger European dataset but for the Apennine they used only 36 relevés, not considering several papers such as: $[34,37,38]$ and our unpublished data). We also observed many differences from a floristic viewpoint between the diagnostic species reported by Košir et al. [42] (see Tab. S1) and those indicated in our Tab. S2, as they only partially overlap; some of the diagnostic species in the "Apennine-Balkan" group (Ostryo-Tilienion) of Košir et al. [42] are lacking or scarcely present in the Apennine relevés (e.g. Tilia tomentosa, Ruscus hypoglossum) or belong to very different ecological components on the Italian peninsula (e.g. Ornithogalum umbellatum, Ranunculus ficaria).

\section{Conclusions}

(i) Maple-ash woods on the Italian peninsula can be subdivided into 7 distinct groups, based on the syntaxonomical analysis of a large dataset; these only partially correspond to the previously indicated syntaxa based on local floristic analyses. Overlapping associations belong to the groups that are not geographically or biogeographically isolated. (ii) Among the woods analyzed the Alpine, Apennine and Balkan coenoses are floristically and phytogeographically well-differentiated from each other. (iii) The floristic differentiation observed is therefore due to the marked differences in their flora and reflects the phytogeographic subdivision of the Eurosiberian region [84], which supports the separation of the Alpine and Apennine-Balkan provinces and, within the latter, the Apennine and Illyrian sectors. The results presented here could play an important role in the transfer of floristic-ecological information to the syntaxonomic level, in order to create syntaxa (in particular above the association level) that can better reflect the chorological gradients present in the Acer-Fraxinus woods of the Alpine area and southern Europe. The indication emerging from this study is that the syntaxonomic schemes proposed by Košir et al. [42] on a geographic-ecological basis, which include the Apennine and Balkan coenoses in a single suballiance, do not seem to correspond very well to the differences that we identified on a phytogeographical and floristic basis. Alternatively, emphasising the chorological and floristic differences that we proved to be present, we can distinguish between two separate suballiances, coinciding with these two sectors, within which we can identify various association groups based on ecological requirements. If we adopt this choice, our analyses show that the suitable diagnostic species for an Appennine suballiance are: Acer obtusatum, Cardamine kitaibelii, Cephalanthera damasonium, Daphne laureola, Digitalis micrantha, Ilex aquifolium, Helleborus bocconei, pulmonaria apennina, $\mathrm{Sa}$ nicula europaea, Chaerophyllum temulum (see Tab. S1, Tab. S2).
For this suballiance we propose the name: Acerenion obtusatipseudoplatani suball. nova hoc loco, holotypus: Ornithogalo sphaerocarpi-Aceretum pseudoplatani Taffetani 2000 [31]. The distribution area of this new suballiance is restricted to the Apennine sub-province of the Apennine-Balkan province [85]. The suballiance Ostryo carpinifoliae-Tilienion platyphylli Košir, Čarni and Di Pietro 2008 may be restricted to local habitat dominated by Tilia-species, especially in the north-eastern part of Italy and in the Balkan parts of the Apennine-Balkan province.

\section{Supplementary material}

The following supplementary material for this article is available online at https://pbsociety.org.pl/journals/index.php/ asbp/rt/suppFiles/asbp.2011.037/0:

1. Tab S1. Italian peninsula Acer-Fraxinus dominated conenoses (the groups correspond to the classification in Fig. 1).

2. Tab S2. Synoptic table with constancy classes (1-1-20\%, $2-21-40 \%$, etc.) of central and southern European AcerFraxinus dominated relevés (the groups correspond to the classification in Fig. 2).

\section{References}

1. EEC interpretation manual of European Union habitats, version EUR27. Brussels: Commission of the European Communitie; 2007.

2. Biondi E, Blasi C. Habitat Italia [Internet]. Manuale Italiano di interpretazione degli habitat della Direttiva 92/43 SBI. 2009 [cited 2010 Jun 1]; Available from: http://vnr.unipg. it/habitat/

3. Clot F. Les érablais européennes: essai de synthèse. Phytocoenologia. 1990;18(4):409-564.

4. Ellenberg H. Vegetation ecology of Central Europe. 4 th ed. Cambridge: Cambridge University Press; 1988.

5. Klika J. Nauka o rostlinných společenstvech (fytocenologie). Prague: ČSAV; 1955.

6. Beger H. Assoziationsstudien in der Waldstufe des Schanfiggs. Switzerland: Bischofberger \& Hotzenköcherle; 1922.

7. Issler E. Les associations végétales des Vosges méridionales et de la plaine Rhénane Avoisinante: Les forêts. Bull Soc Hist Nat Colmar. 1925;18:68-142.

8. Koch W. Die Vegetationseinheiten der Linthebene. Jahrb St Gall Naturwiss Ges. 1926;61:1-144.

9. Libbert W. Die Vegetation des Fallsteingebietes. Mitt Flor Soz Arbeitsgem Niedersachsen. 1930;2:1-66.

10. Moor M. Zur Systematik der Fagetalia. Ber Schweiz Bot Ges. 1938;48:417-469.

11. Moor M. Die Fagion-Gesellschaften im Schweizer Jura. Beitr Geobot Landesaufn Schweiz. 1952;31:1-201.

12. Etter H. Über die Waldvegetation am Südostrand der Schweizerischen Mittellandes. Mitt Schweiz Anst Forstl Versuchsw. 1947;48:591-930.

13. Oberdorfer E. Süddeutsche Pflanzengesellschaften. Pflanzensoziologie. 1957;10:1-564.

14. Oberdorfer E. Pflanzensoziologische Exkursionsflora. Stuttgart: Ulmer; 1990.

15. Marinček L. Beitrag zur Kenntnis der Edellaubwälder Illyriens. In: Illyrische Einstrahlungen im ostalpin-dinarischen Raum: Symposium in Keszthely, 25-29 Juni 1990. 
Keszthely: Georgikon Faculty, University of Pannonia; 1990. p. 51-58.

16. Marinček L. Prispevek k poznavanju gozdov plemenitih listavcev v Sloveniji. Biol Vestn. 1996;40:87-99.

17. Dakskobler I. Gozdna vegetacija Zelenega potoka v dolini Idrije (zahodna Slovenija). Razprave IV. Razreda SAZU. 1999;40:103-194.

18. Košir P, Prispevek K. Sinsistematiki združbe HacquetioFraxinetum excelsioris Marinček in Wallnöfer et al. 1993. Hacquetia. 2002;1:109-128.

19. Bartsch J, Bartsch M. Der Schlichtwald und der BachEschenwald. Angew Pflanzensoz. 1952;8:1-109.

20. Müller T. Vegetationskundliche Beobachtungen im Naturschutzgebiet Hohentwiel. Veröff Landesst Natursch Landschaftspfl Baden-Württ. 1966;34:15-61.

21. Müller T. Verband: Tilio platyphylli-Acerion pseudoplatani Klika 55. In: Oberdorfer E, editor. Süddeutsche Pflanzengesellschaften. Wälder und Gebüsche. Jena: Gustav Fischer Verlag; 1992. p. 173-192.

22. Moor M. Ahornwälder im Jura und in den Alpen. Phytocoenologia. 1975;2:244-260.

23. Chytrý M, Sadlo J. Tilia-dominated calcicolous forests in the Czech Republic from a central European perspective. Ann Bot (Roma). 1997;55:105-126.

24. Poldini L, Nardini S. Boschi di forra, faggete e abieteti in Friuli (NE Italia). Studia Geobot. 1993;13:215-298.

25. Lasen C, Urbinati C. Typology and ecology of maple-linden and maple-ash forest communities: preliminary considerations in north-eastern Italian prealpine ranges. Sauteria. 1995;6:21-56.

26. Ferrari C, Pirola A, Ubaldi D. I faggeti e gli abieti-faggeti delle Foreste demaniali casentinesi in provincia di Forlì. Not Fitosoc. 1979;14:41-58.

27. Pedrotti F. Sulla vegetazione dei monti della Laga (Italia centrale). Giorn Bot Ital. 1982;115(6):354.

28. Maccherini S, Gabellini A, Angiolini C, Chiarucci A, Morrocchi D, Castagnini P, et al. Carta della vegetazione Riserva Naturale "Monte Labbro". Florence: SELCA; 2000.

29. de Dominicis V, Gabellini A, Viciani D, Morrocchi D, Gonnelli V. Contributo alla conoscenza vegetazionale della Riserva Naturale del sasso di Simone (Toscana Orientale). Atti Soc Tosc Sci Nat Mem ser B. 2002;108:7-26.

30. Viciani D, Gabellini A, Gonnelli V, de Dominicis V. La vegetazione della Riserva Naturale Alpe della Luna (Arezzo, Toscana) ed i suoi aspetti di interesse botanico-conservazionistico. Webbia. 2002;57(1):153-170.

31. Taffetani F. Serie di vegetazione del complesso geomorfologico del Monte dell'Ascensione (Italia centrale). Fitosociologia. 2000;37(1):93-151.

32. Brullo S, Scelsi F, Spampinato G. La vegetazione dell'Aspromonte. Studio fitosociologico. Reggio Calabria: Laruffa; 2001.

33. Biondi E, Casavecchia S, Pinzi M, Allegrezza M, Baldoni $M$. The syntaxonomy of the mesophilous woods of the Central and Northern Apennines (Italy). Fitosociologia. 2002;39(2):71-93.

34. Allegrezza M. Vegetazione e paesaggio vegetale della dorsale del Monte San Vicino (Appennino Centrale). Fitosociologia. 2003;40(1 suppl):3-118.

35. Catorci C, Gatti R, Sparvoli D. Vegetazione e paesaggio vegetale della dorsale del Monte San Vicino (Appennino Centrale). Fitosociologia. 2003;40(2):43-53.

36. Angiolini C, Foggi B, Viciani D, Gabellini A. Contributo alla conoscenza sintassonomica dei boschi del Tilio-Acerion Klika 1955 dell'Appennino centro-settentrionale (Italia centrale). Fitosociologia. 2005;42(1):109-119.

37. Pirone G, Ciaschetti G, Frattaroli AR. La vegetazione della Riserva Naturale Regionale "Abetina di Rosello". Fitosociologia. 2005;42(1):121-137.

38. Paura B, Cutini M. Sull'ecologia delle foreste del TilioAcerion Klika 1955 in Molise e considerazioni sui caratteri cenologici e fitogeografici dei boschi di forra dell'ppennino centro-meridionale. Webbia. 2006;61(1):145-165.

39. Ubaldi D. La vegetazione boschiva d'Italia manuale di fitosociologia forestale. Bologna: CLUEB; 2003.

40. Ubaldi D. La vegetazione boschiva d'Italia manuale di fitosociologia forestale. 2nd ed. Bologna: CLUEB; 2008.

41. Biondi E, Casavecchia S, Biscotti N. Forest biodiversity of the Gargano Peninsula and a critical revision of the syntaxonomy of the mesophilous woods of southern Italy. Fitosociologia. 2008;45(2):93-126.

42. Košir P, Čarni A, Di Pietro R. Classification and phytogeographical differentiation of broad-leaved ravine forests in southeastern Europe. J Veg Sci. 2008;19(3):331-342. http:// dx.doi.org/10.3170/2008-8-18372

43. Fukarek P. Prilog poznavanju biljnosocioloških odnosa šuma i šibljaka nacionalnog parka Sutjeska. Odjelenje prirodnih i matematičkih nauka. 1969;3:189-291.

44. Theurillat JP, Aeschimann D, Küpfer P, Spichiger R. Habitats et régions naturelles des Alpes. Colloq Phytosociol. 1994;22:15-30.

45. Theurillat JP, Aeschimann D, Küpfer P, Spichiger R. The higher vegetation units of the Alps. Colloq Phytosociol. 1995;23:189-239.

46. Braun-Blanquet J. Pflanzensoziologie: Grundzüge der Vegetationskunde. 3rd ed. Wien: Springer; 1964.

47. Hill MO. TWINSPAN: a FORTRAN program for arranging multivariate data in an ordered two-way table by classification of the individuals and attributes. Ithaca NY: Section of Ecology and Systematics, Cornell University; 1979.

48. Knollová I, Chytrý M, Tichý L, Hájek O. Local ranges of phytosociological associations: are they reflected in numerical classification? Biologia. 2006;61(1):71-77. http:// dx.doi.org/10.2478/s11756-006-0010-3

49. Glavač VM. O šumi lipe i tise (Tilieto-Taxetum). Sumar List. 1958;1-2:21-26.

50. Pelcer Z. Lipove šume virovitičke bilogore. 2. Kongres ekologia Jugoslavije Zadar-Plitvice; Zagreb. 1979. p. 863-875.

51. Stefanovic V. Fitocenoza javora i lipa (Aceri-Tilietum mixtum, Stef., 1974) u nekim kanjonima dinarida. 2. Kongres ekologia Jugoslavije Zadar-Plitvice; Zagreb. 1979. p. 1083-1102.

52. Accetto M. Corydalido ochroleucae-Aceretum ass. nova v Sloveniji. Razprave IV. Razreda SAZU. 1991;33:89-128.

53. Košir P, Marinček L. Predhodno poročilo o raziskavah javorjevih gozdov v Sloveniji. Acta Biol Slov. 1999;42(3):53-58.

54. Dufrène M, Legendre P. Species assemblages and indicator species: the need for a flexible asymmetrical approach. Ecol Monogr. 1997;67(3):345-366. http://dx.doi. org/10.2307/2963459

55. McCune B, Mefford MJ. PC-ORD: multivariate analysis of ecological data; version 4 for Windows; user's guide. Gleneden Beach OR: MjM Software Design; 1999.

56. Takhtadjian AL, Jeffrey C, Takhadjan AL. Flowering plants: origin and dispersal. Edinburgh: Oliver and Boyd; 1969. 
57. Takhtadjian AL, Cronquist A. Floristic regions of the world. Berkeley CA: University of California Press; 1986.

58. Arrigoni PV. Aspetti corologici della flora sarda. Lav Soc Ital Biogeogr. 1983;8:81-109.

59. Foggi B. Analisi fitogeografica del distretto Appenninico Tosco-Emiliano. Webbia. 1990;44(2):169-196.

60. ter Braak CJF, Šmilauer P. CANOCO reference manual and user's guide to Canoco for Windows: software for canonical community ordination (version 4). Ithaca NY: Microcomputer Power; 1998.

61. Miller AJ. Subset selection in regression. London: Chapman \& Hall; 1990.

62. Cooper DW. The significance level in multiple tests made simultaneously. Heredity. 1968;23(4):614-617. http:// dx.doi.org/10.1038/hdy.1968.79

63. Lepš J, Šmilauer P. Multivariate analysis of ecological data using CANOCO. Cambridge: Cambridge University Press; 2003. http://dx.doi.org/10.1017/CBO9780511615146

64. Tutin TG, Heywood VH, Burges NA, Valentine DH, Walters SM, Webb DA, editors. Flora Europaea. Cambridge: Cambridge University Press; 1968-1980. (vol 2-5).

65. Tutin TG, Burges NA, Charter AO, Edmondson JR, Heywood VH, Moore DM, et al., editors. Flora Europaea. 2nd ed. Cambridge: Cambridge University Press; 1993. (vol 1).

66. Conti F, Abbate G, Alessandrini A, Blasi C. An annotated checklist of the Italian vascular flora. Rome: Palombi Editori; 2005.

67. Conti F, Alessandrini A, Bacchetta G, Banfi E, Barberis G, Bartolucci F, et al. Integrazioni alla checklist della flora vascolare italiana. Natura Vicentina. 2007;10:5-74.

68. Pott R. La evolución postglaciar de los bosques frondosos caducifolios en Europa. Itinera Geobotanica. 1998;(11):31-63.

69. Pott R. Sincronologia e sincorologia dei boschi di faggio (Fagetalia sylvaticae) nell'Europa centrale. Giorn Bot Ital. 1996;130(1):200-213. http://dx.doi. org/10.1080/11263509609439527

70. Pott R. Invasion of beech and establishment of beech forests in Europe. Ann Bot (Roma). 1997;55:27-58.

71. Magri D. Quaternary history of Fagus in the Italian peninsula. Ann Bot (Roma). 1998;56(1):147-154.

72. Watson CS. The vegetational history of the northern Apennines, Italy: information from three new sequences and a review of regional vegetational change. J Biogeogr. 1996;23(6):805-841. http://dx.doi. org/10.1111/j.1365-2699.1996.tb00041.x

73. Ubaldi D. Tipificazione di syntaxa forestali appenninici e siciliani. Ann Bot (Roma). 1995;51(10 suppl):113-128.

74. Maarel E. Vicinism and mass effect in a historical perspective. J Veg Sci. 1995;6(3):445-446. http://dx.doi. org/10.2307/3236245

75. Meusel H, Jäger EJ. Ecogeographical differentiation of the Submediterranean deciduous forest flora. Plant Syst Evol. 1989;162(1-4):315-329. http://dx.doi.org/10.1007/ BF00936924

76. Košir P. Noble hardwood forests of the altimontane belt (Lamio orvalae-Aceretum pseudoplatani P. Košir et Marinček 1999) in Slovenia (western part of the Illyrian floral province). Nat Croat. 2005;14(2):59-86.

77. Košir P. Maple forests of the montane belt in the western part of the Illyrian floral province. Hacquetia. 2005;4:37-82.

78. Košir P, Čarni A. Diversity of noble hardwood forests in Southeastern Europe. Symposium 2006 of the Slovenian Society of Plant Physiology. 2006. p. 72-73.

79. Bertolani-Marchetti D. Pollen paleoclimatology in the Mediterranean since Messinian Time. In: Stanley DJ, Wezel FC, editors. Geological evolution of the Mediterranean Basin. New York: Springer; 1985.

80. Bennett KD, Tzedakis PC, Willis KJ. Quaternary refugia of north European trees. J Biogeogr. 1991;18(1):103-115. http://dx.doi.org/10.2307/2845248

81. Pignatti S. Ecologia del paesaggio. Torino: UTET; 1994.

82. Poldini L. Atlante corologico delle piante vascolari nel Friuli-Venezia Giulia: inventario floristico regionale. Udine: University of Trieste; 1991.

83. Pignatti S. Valori di bioindicazione delle piante vascolari della flora d'Italia. Braun-Blanquetia. 2005;39:1-97.

84. Rivas-Martinez S, Penas A, Diaz TE. Biogeographic map of Europe. León: Cartographic Service, University of León; 2001.

85. Rivas-Martínez S, Rivas-Saenz S. Worldwide bioclimatic classification system [Internet]. 1996-2009 [cited 2010 Jun 1]; Available from: http://www.globalbioclimatics.org 